\title{
"Non, moi je lui dis pas en turc, ou en portugais, ou en, j'sais pas moi en arabe": Exploring teacher ideologies in multilingual/cultural preschool contexts in France
}

\author{
Andrea S. Young \\ University of Strasbourg, School of Education, France \\ EA1339 LiLPa-GEPE
}

Article received 7 February 2017, accepted 9 March 2017, final version 12 April 2017

DOI: http://dx.doi.org/10.5565/rev/jtl3.729

\begin{abstract}
This contribution explores the relationship between language ideologies and teaching with specific reference to the French national education context and in particular with respect to the education of children for whom French, the language of schooling, is not the language spoken in the home. The discourse of three teachers working in multilingual/cultural preschools is examined, revealing both beliefs about languages and practiced language policies underpinned by deep-rooted language ideologies which perpetuate a monolingual habitus. It is argued that in order to challenge the myths which support this monolingual mindset, it is essential to nurture teacher language awareness, underpinned by knowledge, values and a deeper understanding of the complexities of living and learning through multiple languages.
\end{abstract}

Keywords: France, multilingualism, practiced language policy, preschool

\section{Résumé}

Cette contribution explore la relation entre les idéologies linguistiques et les pratiques pédagogiques d'enseignants d'école maternelle en France envers les élèves pour qui la langue de l'école n'est pas la langue parlée à la maison. L'analyse de discours de trois enseignantes qui travaillent dans des contextes linguistiquement et culturellement hétérogènes, révèle des représentations ainsi que des politiques linguistiques pratiquées, ancrées dans des idéologies qui font perdurer l'habitus monolingue. Dans l'optique de remettre en question les mythes qui sous-tendent cette vision monolingue de l'apprentissage et de l'enseignement, le développement d'une conscience linguistique, nourrie par des connaissances, des valeurs et une meilleure compréhension des complexités associées à l'apprentissage et à l'enseignement en milieu multilingue, est proposé.

Mots clés: France, plurilinguisme, politique linguistique pratiquée, école maternelle

\section{Resum}

Aquest article explora la relació entre ideologies lingüístiques i pràctiques educatives dels mestres de preescolar a França, en particular mestres qui treballen amb alumnes per als que la llengua de l'escola no és l'idioma que parlen a casa. Anàlisi de discurs de tres professors que treballen en contextos lingüística i culturalment heterogenis revela que les seves representacions i les seves polítiques lingüístiques practicades, són arrelades en ideologies que perpetuen l'habitus monolingüe. Per tal de desafiar els mites subjacents a aquesta visió monolingüe d'aprenentatge i ensenyament, cal desenvolupar la 
consciència lingüística, alimentada pels coneixements, valors i comprensió de les complexitats associades amb l'aprenentatge i l'ensenyament d'idiomes multilingüe.

Paraules clau: França, el multilingüisme, la política lingüística practicada, llar d'infants

\section{Introduction}

In this article, I will explore the relationship between language ideologies and teaching with specific reference to the French national education context. Particular attention will be paid to the education of those children for whom French, the language of schooling, is not the language spoken in the home.

My starting point will be to listen to the voices of a variety of experienced teachers as they discuss language learning and teaching in a multicultural environment. From these windows into teacher cognition, what teachers know, believe and think (Borg, 2003), I will firstly explore how language ideologies specific to the French context have evolved and endured from the revolutionary period to the present day. Secondly, I will identify and analyse traces of these ideologies to be found within the teachers' discourses, demonstrating how language ideologies influence teachers' beliefs about languages and consequently their practiced language policies (Bonacina-Pugh, 2012). ${ }^{1}$ Finally, I will argue that challenging deep-rooted monolingual ideologies and ensuring appropriate, effective teaching in a multilingual/multicultural context does not rely on the provision of materials, pedagogical tools and toolkits, nor the formulation of top-down policy in isolation, but the nurturing of teacher language awareness (Pomphrey \& Burley, 2009). Such awareness is underpinned by knowledge, values and a deeper understanding of the complexities of living and learning through multiple languages.

\section{Listening to and contextualising voices: beliefs, ideologies and practiced language policies}

The following extracts ${ }^{2}$ are from interviews conducted in 2014 with three nursery school teachers, Mme X, Mme Y \& Mme Z., working in the Alsace region of north eastern France.

là ça fait depuis une semaine que j'ai fait des groupes donc là ils sont plus ensemble pour le travail. Mais sinon euh voilà ils s'expliquaient en turc comment faire le travail ils restaient toujours ensemble donc là forcément maintenant j'ai un petit peu essayé de séparer les choses donc ils se retrouvent un peu moins ensemble. Mais là dans la cour de récréation ils étaient de nouveau tous les deux 
[there it's been a week since I made the groups so there they are not together anymore for working. Well otherwise well they were explaining to each other in Turkish how to do the work they always stayed together so there now obviously I've tried to separate things out a bit so they find themselves together a bit less. But there in the playground they were both again]

(Mme X, teacher of four-year-olds)

je suis persuadée que on a beau répéter, répéter en journée, s'il y a pas un minimum de français à la maison, s'il y a que la langue étrangère à la maison, les quelques heures de français à l'école ne suffisent pas.

[I am convinced that no matter how often we repeat, repeat during the day, if there isn't a minimum amount of French at home, if there is only the foreign language at home, the few hours of French at school are not enough.]

(Mme Z, teacher of five-year-olds)

Mais quand je vois des fois que les enfants paniquent à cause de, de quelque chose que je leur dit ou, alors que je sais qu'ils sont en mesure de comprendre et que la maman derrière veut traduire juste pour rassurer l'enfant je dis non! Il faut qu'ils comprennent ça en français! "Viens prendre ton prénom », moi je vois pas pourquoi la maman le traduit en turc. Il faut qu'il comprenne qu'il entre, qu'il prend son prénom, qu'il le mette là-bas, que après il prenne le jeu d'ici, les crayons de couleurs d'ici! Non, moi je lui dis pas en turc, ou en portugais, ou en, j'sais pas moi en arabe!

[But when I see sometimes the children panicking because of, of something I tell them or, when I know for a fact they are capable of understanding and the mother behind wants to translate just to reassure the child I say no! They have to understand that in French! "Come and take your first name", I don't understand I don't why the mother translates it into Turkish. He has to understand that he comes in, that he takes his first name, that he puts it over there, that after that he takes the game from here, the coloured pencils from here! No, I tell him not in Turkish, or in Portuguese, or in I don't know what, Arabic!]

(Mme Y, teacher of five-year-olds, 2014)

This type of discourse is not unusual amongst teachers in France (see Young, 2014a, 2014b for further examples and discussion). The above extracts reveal some of the practiced language policies, defined by Bonacina-Pugh as policies "found within language practices" (Bonacina-Pugh, 2012, p. 216) of the three teachers interviewed. What is striking about these extracts is the amount of energy which the teachers appear to devote to excluding all languages other than French from the classroom. That the teachers feel a responsibility and undoubtedly a certain pressure to equip their pupils with enough French to allow them to 
function in the classroom, to socialise with the French-speaking pupils and to access learning across the curriculum through the French language is understandable; as Mme Y says, "Il faut qu'ils comprennent ça en français!” (They have to understand that in French!). But that this should be achieved through the prohibition and negation of their first language does not equate with research-based evidence which underlines the importance of promoting the transfer of skills and knowledge between languages (see Cummins, 2011 for a review of the research). These findings present a strong case for the recognition of pupils' linguistic skills, irrespective of the language, and the support of their use as cognitive tools for learning (Cummins \& Persad, 2014).

If teachers are not basing their practiced language policies on research findings, what are they basing them on? The response is multiple, complex and frequently the product of engrained monolingual language ideologies (Shohamy, 2006), deeply rooted in the social, historical, economic and political context. In France, there is a strong relationship between the national language and the values of the République française which continues to influence teachers' attitudes towards both the national language and languages other than French. The French language is regarded as the bedrock of the nation, the common medium of expression which unites citizens; as such, it is enshrined in the French constitution as the language of the République (article 2 of the Constitution, modified by constitutional law $n^{\circ} 95-880$ on 4 August 1995). The official status of the French language also has repercussions on the relative importance of other languages in France. For example, the European Charter for Regional or Minority Languages remains unratified by France (Council of Europe, 2017) and parliamentary debates on this subject arouse strong national and protectionist feelings amongst some members of parliament who fear that recognition of other languages might undermine the status of French.

\section{Historical perspective: Revisiting the past to understand the present}

In order to understand where these attitudes originate and what they are founded upon, it is necessary to briefly revisit the language policies and planning implemented by the government from the time of the French Revolution to the present day (see Kremnitz, 2013 for a more detailed account). These comprise a national strategy to create a unified state with a shared and unique language, French. Following the revolution, a report produced by Abbé Grégoire (1790) stated that French was not spoken in four out of five administrative areas, or départements, in France (Broudic, 2013). In order to remedy this situation and allow all 
citizens equal rights and emancipation through developing competence in the French language, the 1794 Lakanal education law stipulated that instruction was to be carried out in French and that local languages were only to be used for learning support purposes (ibid.). By 1864, according to a report commissioned by the then Minister for Education, Victor Duruy, the number of départements where children aged 7 to 13 could neither speak nor write in French stood at 57\% (Webet, 1983 in Broudic, 2013). A further law in 1880 reinforced the status of French as the sole language to be used in school (Chanet, 1996, in Broudic, 2013).

The central role played by school, in particular since 1882 when compulsory schooling was introduced for all children between the ages of 6 and 13 (Broudhic, 2013), in enforcing "la langue de la République" across the length and breadth of the country needs to be acknowledged. One of the reported means of enforcement, was to encourage pupils to denounce their fellow classmates for using their local language, rather than French. This method was still frequently employed during the period following the Second Word War in regions all over France, from Brittany to Alsace to Provence. It was done through the passing of a symbolic object such as a ring or a placard from one child to another whenever the forbidden language was heard within the school premises (ibid.). Some researchers have referred to the francization process supported by schools and also by national conscription, effectively delegitimising regional languages, as "the promotion of monolingualism in the name of liberté, égalité et fraternité... a form of internal colonialism" (Hechter, 1975, in Heller, 2009: 4). Over the centuries, schools, in their attempts to mould future French citizens, have effectively adopted practices, underpinned by a once overt, now covert, ideology, which seek to promote the French language through banning all others.

With the decline in family transmission of regional languages in France (Filhon, 2010), their perceived potential threat to French has waned; such languages may even be found on the school curriculum as school subjects or as the medium of instruction in bilingual classes. However, the monolingual mindset persists and prohibitory practiced languages policies previously directed towards Alsatian, Breton, Occitan etc. are now directed towards languages spoken by persons of immigrant background.

\section{The monolingual inheritance}

In spite of European language policies advocating a plurilingual approach to language learning (Little, 2012; Beacco et al., 2010), the implicit norm at school in France is monolingual and monocultural. The language(s) of the home and the language(s) of schooling 
coexist within the individual on a personal level, but on an institutional level, languages other than those on the curriculum are frequently ignored and sometimes regarded as a handicap or a hindrance to the acquisition of French. A report compiled by the Inspectorate (M.E.N., 2010) specifically states that even though the constitution recognises French as the sole official language, this should not prohibit teachers from developing pedagogical practices which value heritage languages. However, inclusive approaches which attempt to capitalise on funds of knowledge (González, Moll, \& Amanti, 2005) and linguistic skills cultivated outside school in order to enrich learning and deepen understanding in class remain rare.

In addition to the compartmentalisation of languages into separate, unconnected spaces (languages of the home, the language of instruction, foreign language classes), languages are ranked within an unofficial linguistic hierarchy at school. In a pyramid-like structure, a highly standardised, academic form of French is positioned at the summit, foreign languages recognised by and taught at school in the intermediate position (sometimes in competition with standardised forms of indigenous regional languages) and finally, at the foot of the pyramid, lie the neglected languages of migration.

The practiced language policies mentioned by the teachers at the beginning of this article appear to confirm the unrecognised, unvalued and undeveloped learning potential of knowledge and skills in languages other than French. This would seem to be the case in Mme $\mathrm{X}$ 's class, as although she appears to acknowledge that a shared home language, in this case Turkish, can be used by pupils to explain to each other "comment faire le travail" (how to do the work), she negates the power of this cognitive tool by deliberately separating the children for group work. She describes how the two four-year-old cousins frequently sought each other's company, playing together during break time and explaining learning tasks to each other in the classroom, and how she endeavoured to discourage this collaboration. Her use of the word "forcement" (obviously) indicates that she feels there is a shared belief in this practice and the ideology behind it.

The underlying reason as to why Mme $\mathrm{X}$ believes this practice to be appropriate is hinted at in the interview when she talks about encouraging the Turkish-speaking children to mix with the others ("s'ouvrir aux autres"). She suggests that she fears the children will remain within their home language and culture group (Turkish) and not integrate into the class group, posing a threat to class, and potentially national, cohesion. The teaching of shared values and a shared language in support of national unity has always lain at the heart of the French education system, as has already been discussed: of these values, it is the notion of 
laïcité (secularism) in particular which has been prioritised in teacher education (Commissariat général à l'égalité des territoires, 2016) since the attacks in Paris in 2015. In this climate, communautarisme (communalism), staying within one's own community, is viewed as a threat to social cohesion by many French citizens, including teaching professionals.

With regards to Mme X's class, in addition to the fear that the Turkish-speaking children might not fully integrate into the class group, it could also be that the teacher believes that if the two children are separated in class, they will be forced to use French as the language of communication, and that their competences in the language of schooling will therefore develop more quickly. This is a common belief in contexts where a monolingual habitus (Gogolin, 1997) or mindset (Clyne, 2005 in Hajek \& Slaughter, 2014) is dominant and where languages are viewed as if they are in competition rather than functioning in a complementary manner.

Traces of this belief can be observed in the extract from the interview with Mme $\mathrm{Z}$ in which she expresses the difficulty she experiences in supporting children for whom the language of the home is not the language of the school. She says she is convinced ("persuadée") that if there is not a "minimum" input of French in the home, the few hours ("quelques heures") of French at school are insufficient ("ne suffisent pas"). By considering the two languages with which the children are in contact as vying with each other for time and space, Mme Z reveals a monolingual conception of how multilingual learners function, using their languages separately, rather than in tandem. Mme Y's comment: "moi je vois pas pourquoi la maman le traduit en turc" (I don't see why the mother translates it into Turkish), also reveals an incapacity to appreciate the reinforcement of meaning through the use of the home language. Yet research supports Cummins' (1979) interdependence hypothesis which maintains that knowledge and skills can be transferred from one language to another and that this process facilitates meaning making and deeper understanding.

Furthermore, it should be noted that pre-primary children of this age spend between 23 and 31 hours a week at school, depending on whether they stay for lunch or not. If they attend after-school care, this can increase to 50 hours per week. They consequently spend most of their waking, active day at school during weekdays. Exposure to the language of schooling therefore represents more than just the few hours ("quelques heures") mentioned by Mme Z. However, with up to 32 children in an ordinary preschool class and only one teacher, interaction in French may be limited. This lack of frequent one-on-one interaction and 
interactive meaning making renders acquisition of the language of schooling difficult for children who speak a language other than French. Yet many teaching professionals still believe that children will acquire the language of the school through simply being immersed in or exposed to it, and often, like Mme Z, they place the responsibility for limited acquisition of French with families, not schools.

Knowledge about second language acquisition is clearly insufficient and training in how to support learners for whom French is an additional language is practically non-existent (M.E.N., 2010). Mme Z reveals the nature of her teaching strategies and expresses her exasperation with the ineffectual provision of language support through the repetition of the verb "répéter" (to repeat). Repetition of lexical items, akin to the memorisation of foreign language vocabulary lists may be appropriate in certain situations, but for very young learners a motivating, language rich environment in which meaningful interaction takes place is key to their language acquisition, as is underlined in the national curriculum for pre-primary (M.E.N., 2015).

Another feature of Mme Z's discourse is the dominant position she ascribes to French. In this way, she reveals the underlying language hierarchy previously referred to in which languages are ranked according to perceived importance, and where the language of the home is relegated to the position of foreign language ("langue étrangère").

Her use of the term "langue étrangère" suggests her own incapacity to decentre, given that from the child's perspective this language is not foreign, but intimately familiar and personal as her/his language of primary socialisation in which family relationships are forged. For teachers with limited knowledge about language and or an incapacity to decentre and empathise (viewing the world from another perspective), the vacuum left by a lack of research-based knowledge may be filled by what Grosjean (2010) terms bilingual myths. For example, they may believe that multilinguals mix languages due to confusion and/or lack of competence and that consequently bi/multilingualism is harmful for both linguistic and cognitive development. Such bilingual myths lead them to uphold an institutional monolingual habitus through a variety of practiced language policies, such as expecting parents to speak the language of schooling at home with no consideration of the linguistic competences and preferences of the family, as does Mme Z. Another example is the banning of learners' home languages from the classroom, as does Mme Y when she says "non!" to a mother translating into the home language for her child as he enters the classroom, transitioning from his home environment to that of the pre-school. Sometimes teachers even 
attempt to prevent children from using their home languages in the playground (see Ağirdağ, Jordens \& Houtte, 2014, for examples from the Belgian context). Such practiced language policies have been discussed by some researchers within the framework of language rights and as such are viewed as acts of linguicism (Skutnabb-Kangas, 2008) or glottophobie (Blanchet, 2016) due to their exclusive and discriminatory nature. Perhaps Mme X is aware that her practice of separating the Turkish-speaking children is questionable, given that she nuances her expressed belief through the use of the words "un petit peu" and "un peu" referring to the separating of the children, as if while expressing these views she becomes aware, possibly as a result of the interview situation, that this may not be an appropriate action.

\section{Challenging monolingual ideologies through the nurturing of teacher language awareness}

However, not all teachers in France adhere to the monolingual vision of a French only policy at school. There are examples of inclusive practiced language policies scattered throughout France (see Mary \& Young, 2017; Krüger, Thamin, \& Cambrone-Lasnes, 2016; Simon \& Sandoz, 2008; Clerc, Cortier, Longeac, \& Oustric, 2007; Hélot \& Young, 2006; Auger \& Balois, 2005). Nonetheless, such initiatives remain the exception rather than the rule, in spite of top-down policies which advocate a plurilingual inclusive approach (MEN, 2015).

Whilst acknowledging official policy documents as powerful instruments, especially in centralised countries such as France where all teachers are civil servants, top-down, I argue, as do Bonacina-Pugh (2012) and Spolsky (2004), that it is the transition from paper to classroom, the enactment of policies, the bottom-up, practiced language policies which have the greatest impact on learning due to their repetitive and personalised nature. Macro-level government policy effectively devolves decision-making to micro-level agents who negotiate policy through the micro-level pedagogical activities (Liddicoat, 2014). This view relocates the focus of power and potential for innovation in the classroom firmly with the teacher who, through her/his daily actions, words and attitudes towards the languages of his/her pupils, negotiates and reinterprets top-down policy (Valdiviezo, 2009) at the micro level of the classroom.

Recognising teachers as key agents in language empowerment, and critiquing the monolingual lens through which language education is frequently framed, some researchers have advocated a multilingual turn which recognises and builds on the multiple competencies 
of bi/multilingual learners (May, 2014; Conteh \& Meier, 2014). As facilitators of this multilingual turn, teachers need to develop their knowledge about and their awareness of language. Language awareness has been defined as "a person's sensitivity to and conscious awareness of the nature of language and its role in human life" (Donmall, 1985, p. 7, in James \& Garrett, 1991, p. 4). Language awareness develops as a result of greater understanding, empathy, experience of and knowledge about language and languages. Knowledge about language is a key component of language awareness, without which teachers may be aware of the linguistic and cultural difficulties experienced by the pupils for whom the language of the home is not the language of schooling and empathetic towards their situation, but powerless to act without the necessary knowledge and understanding.

Consequently, teachers may struggle to ensure access to the curriculum through the language of schooling for these pupils and fail to develop a shared common culture and a sense of belonging with a view to promoting social cohesion. This uncomfortable professional situation may lead teachers to hold families responsible for lack of proficiency in the language of schooling, rather than questioning their own professional competences and responsibilities, as found by Pulinx, Van Avermaet, \& Agirdag (2015) in a study in Flanders, and much as Mme Z does.

Given that many teachers feel ill-equipped to meet these challenges (Thomauske, 2013; Cajkler \& Hall, 2012; Jensen, 2010), the role of initial teacher education and continuing professional development programmes in preparing and supporting them to play a positive role and to function effectively in culturally and linguistically diverse contexts is clearly of paramount importance. As previously mentioned, teacher education in France in this domain is inadequate (M.E.N., 2010), although some initial teacher education programmes have attempted to introduce elements of language awareness into their packed curricula (Krüger et al., 2016; Mary \& Young, 2010). However, time and space are scarce in these often intensive, short programmes which, given the deep-seated nature of beliefs and attitudes, poses an additional challenge to the development of critical language awareness with a view to contesting the monolingual mindset.

Progress has recently been made in this direction through the forging of two additional pathways. The first pathway has been opened up by non-governmental organisations in France such as DULALA (D’Une Langue A L'Autre) and Familangues. In an attempt to bridge the knowledge gap relating to multilingualism in French society, these organisations use evidence-based research to allow both parents and professionals to become better 
informed and to question the monolingual habitus: this is done through informal workshops, meetings, conferences and online resources. .

A second pathway is currently under co-construction by practitioners and researchers working together (Mary \& Young, 2017; Krüger et al., 2016). Acknowledging the strategic position of teachers as interpreters and negotiators of language policies, acting as the "final arbiters of language policy implementation" (Menken, 2008, p. 5), several teacher educators/researchers have decided to work alongside experienced teachers both in and out of the classroom. Their goal is to observe, record and analyse when, where and how teachers act as language policy arbiters. They then share and interpret the data with the teachers in order to understand more fully the challenges and opportunities of teaching in a linguistically and culturally diverse setting. These practice-orientated, collaborative approaches in research projects invested and enacted by teachers appear to offer an alternative route towards cultivating teacher language awareness and facilitating ideological shifts (see the CUNYNYSIEB project website for an illuminating example). The development of a deeper understanding of the complex issues relating to language, ideology and learning, illuminates the role of all teachers as facilitators in language education processes, as enactors of policies (Menken \& García, 2010; Menken, 2008) and as agents of language empowerment.

\section{Acknowledgements:}

Acknowledgements to Marie Scheffer, Masters student at the School of Education (ESPE), University of Strasbourg, who collected and transcribed the data.

\section{References:}

Ağirdağ, O., Jordens, K. \& Van Houtte, M. (2014). Speaking Turkish in Belgian primary schools: Teacher beliefs versus effective consequences. bilig, 7-28.

Auger, N. \& Balois, J.-M. (2005). Comparons nos langues: démarche d'apprentissage du français auprès d'enfants nouvellement arrives. CRDP de l'Académie de Montpellier: Scérén.

Beacco, J.-C., Byram, M., Cavalli, M., Coste, D., Egli Cuenat, M., Goullier, F. \& Panthier, J. (2010). Guide for the development and implementation of curricula for plurilingual and intercultural education. Strasbourg: Language Policy Division of Council of Europe.

Blanchet, P. (2016). Discriminations: combattre la glottophobie. Paris: Éditions Textuel.

Bonacina-Pugh, F. (2012). Researching 'practiced language policies': insights from conversation analysis. Language Policy, 11, 213-234. DOI 10.1007/s1093-012-9243-x

Borg, S. (2003). Teacher cognition in language teaching: A review of research on what language teachers think, know, believe, and do. Language Teaching, 36, 81-109. doi.org/10.1017/S0261444803001903 
Broudic, F. (2013). L'interdit de la langue première à l'école. In Kremnitz, G. (ed.) Histoire sociale des langues de France (pp. 353-373). Rennes: Presse universitaire de Rennes.

Cajkler, W. \& Hall, B. (2012). Multilingual primary classrooms: an investigation of first year teachers' learning and responsive teaching. European Journal of Teacher Education, 35, 213-228. http://dx.doi.org/10.1080/02619768.2011.643402

Chanet, J. F. (1996). L'école Républicaine et les petits patries. Aubier, France: SLE.

Clerc, S., Cortier, C., Longeac, A. \& Oustric, G. (2007). Place et intérêt des pratiques artistiques, interculturelles et interlinguistiques dans les dispositifs d'accueil et d'enseignement/apprentissage pour les élèves allophones. Ela. Etudes de linguistique appliquée, 147, 317-328. http://www.cairn.info/revue-ela-2007-3-page-317.htm

Clyne, M. (2005). Australia's language potential. Sydney: University of NSW Press.

Commissariat général à l'égalité des territoires (2016). Laïcité : un plan national pour former les acteurs de terrain. (14/04/17). Retrieved from: http://www.cget.gouv.fr/sites/cget.gouv.fr/files/atoms/files/en-bref-19-cget-062016.pdf

Conteh, J. \& Meier, G. (2014). The multilingual turn in languages education: Opportunities and challenges. Bristol: Multilingual Matters.

Council of Europe. (14/04/17). Signatures and ratifications of the European Charter for regional or minority languages. Retrieved from: http:/www.coe.int/en/web/europeancharter-regional-or-minority-languages/signatures-and-ratifications

CUNY-NYSIEB. City University of New York - New York State initiative on emergent bilinguals. (14/04/17). Retrieved from: http://www.cuny-nysieb.org/

Cummins, J. (1979). Linguistic interdependence and the educational development of bilingual children. Review of educational research, 49, 222-251.

Cummins, J. (2011). Putting the evidence back into evidence-based policies for underachieving students. Language Policy Division, Directorate of Education and Languages, DGIV Council of Europe, Strasbourg. Retrieved from: https://www.coe.int/t/dg4/linguistic/Source/.../JimCummins-textPostForum_EN.doc

Cummins, J., \& Persad, R. (2014). Teaching through a multilingual lens: the evolution of EAL policy and practice in Canada. Education Matters, 2, 3-40. http://em.journalhosting.ucalgary.ca/index.php/em/article/view/67/34

Donmall, B. G. (1985). Language awareness. London: Centre for Information on Language Teaching and Research.

D’Une Langue À L'Autre. (14/04/17). Retrieved from: http://www.dulala.fr/

Familangues. (14/04/17). Retrieved from: http://familangues.org/

Filhon, A. (2010). Transmission familiale des langues en France: Èvolutions historiques et concurrences. Annales de démographie historique, 119, 205-222. DOI: 10.3917/adh.119.0205

Gogolin, I. (1997). The "monolingual habitus" as the common feature in teaching in the language of the majority in different countries. Per Linguam, 13, 38-49. http://dx.doi.org/10.5785/13-2-187

González, N., Moll, L. C. \& Amanti, C. (2005). Funds of knowledge: Theorizing practices in households, communities, and classrooms. Mahwah, New Jersey: Routledge.

Grosjean, F. (2010). Bilingual: Life and reality. London, England: Harvard University Press.

Hajek, J. \& Slaughter, Y. (2014). Challenging the monolingual mindset. Bristol: Multilingual Matters.

Hechter, M. (1975). Internal colonialism: The Celtic fringe in British national development. Berkeley: University of California Press.

Heller, M. (2009). Bilingualism: a social approach. London: Palgrave Macmillan. 
Hélot, C., \& Young, A. (2006). Imagining multilingual education in France: A language and cultural awareness project at primary level. In O. Garcia, T. Skutnabb-Kangas \& M.E. Torres-Guzman (Eds.) Multilingual schools: Languages in education and glocalization (pp. 69-90). Bristol: Multilingual Matters.

James, C., \& Garrett, P. (1991). Language awareness in the classroom. Harlow: Longman.

Jensen, B. (2010). The OECD teaching and learning international survey (TALIS) and teacher education for diversity. Educational Research and Innovation, 63-91. Oecd.ilibrary.org

Kremnitz, G. (ed.) (2013). Histoire sociale des langues de France. Rennes: Presse universitaire de Rennes.

Krüger, A.-B., Thamin, N. \& Cambrone-Lasnes, S. (2016). Diversité linguistique et culturelle à l'école: Accueil des élèves et formation des acteurs. Paris: Editions L'Harmattan.

Liddicoat, A. J. (2014). The interface between macro and micro-level language policy and the place of language pedagogies. International Journal of Pedagogies and Learning, 9, 118-129. DOI 10.1080/18334105.2014.110820

Little, D. (2012). Meeting the challenge of multilingual classrooms: exploiting plurilingual repertoires, managing transitions and developing proficiency in the language(s) of schooling. Strasbourg: Council of Europe. Retrieved from: https://www.coe.int/t/dg4/linguistic/Source/...Conf/SemMarch12_Report_EN.pdf

Mary, L., \& Young, A. (2010). Preparing teachers for the multilingual classroom: Nurturing reflective, critical awareness. In S.H. Ehrhart, C. Hélot \& A. Le Nevez (Eds.) Plurilinguisme et formation des enseignants: Une approche critique / Plurilingualism and teacher education: a critical approach (195-219). Frankfurt: Peter Lang.

Mary, L., \& Young, A. (2017). From silencing to translanguaging: turning the tide to support emergent bilinguals in transition from home to pre-school. In A. Wedin, J. Rosén, B.A. Paulsrud \& B. Straszer (Eds.) Translanguaging and education: New perspectives from the field (pp. 108-128). Bristol: Multilingual Matters.

May, S. (2014). The multilingual turn: Implications for SLA, TESOL, and bilingual education. Routledge.

M.E.N. (2010). Rapport annuel des Inspections générales 2009. Paris: Ministère de l'éducation nationale; Ministère de l'enseignement supérieur et de la recherche.

M.E.N. (2015). Programme d'enseignement de l'école maternelle. Paris: Ministère de l'éducation nationale, BO spécial du 26 mars 2015.

Menken, K. (2008). English learners left behind: Standardized testing as language policy. Bristol: Multilingual Matters.

Menken, K., \& García, O. (2010). Negotiating language education policies. New York \& London: Routledge.

Pomphrey, C., \& Burley, S. (2009). Teacher language awareness education and pedagogy: a new discursive space. Language Awareness, 18, 422-433. DOI: 10.1080/09658410903197314

Pulinx, R., Van Avermaet, P. \& Agirdag, O. (2015). Silencing linguistic diversity: the extent, the determinants and consequences of the monolingual beliefs of Flemish teachers. International Journal of Bilingual Education and Bilingualism, 1-15. DOI: 10.1080/13670050.2015.1102860

Shohamy, E. (2006). Language policy: Hidden agendas and new approaches. Abingdon \& New York: Routledge.

Simon, D.-L. \& Sandoz, M.-O. (2008). Faire vivre et développer le plurilinguisme à l'école: les biographies langagières au cœur de la construction d'identités plurielles et du lien Revue de didactologie des langues-cultures et de lexiculturologie, 265-276. 
Skutnabb-Kangas, T., \& McCarty, T.L. (2008). Key concepts in bilingual education: Ideological, historical, epistemological, and empirical foundations. In Encyclopaedia of language and education (pp. 1466-1482). New York: Springer.

Spolsky, B. (2004). Language policy. Cambridge: Cambridge University Press.

Thomauske, N. (2013). Children's home languages in early childhood education systems: Handicap or asset. In D.B. Napier, \& S. Majhanovich (Eds.) Education, dominance and identity (pp. 83-99). Rotterdam, Boston, Taipei: Sense Publishers.

Valdiviezo, L. (2009). Bilingual intercultural education in indigenous schools: an ethnography of teacher interpretations of government policy. International Journal of Bilingual Education and Bilingualism, 12, 61-79. DOI: 10.1080/13670050802149515

Young, A. S. (2014a). Unpacking teachers' language ideologies: attitudes, beliefs, and practiced language policies in schools in Alsace, France. Language Awareness, 23, 157-171. DOI: 10.1080/09658416.2013.863902

Young, A. S. (2014b). Looking through the language lens: Monolingual taint or plurilingual tint? In J. Conteh \& G. Meier (Eds.). The multilingual turn in languages education: Opportunities and challenges (pp. 89-109). Bristol: Multilingual Matters.

\footnotetext{
${ }^{1}$ I follow Bonacina-Pugh in her spelling of 'practiced'

${ }^{2}$ All translations are by the author.
}

\begin{abstract}
Author's information:
Andrea Young is Senior lecturer in language education (Maître de conférences HDR) at the Université de Strasbourg, France. Her main research areas are educational linguistics and plurilingualism in school settings. Andrea has been involved in a number of European projects in these areas, notably with the European Centre for Modern Languages in Graz.

Email: andrea.young@espe.unistra.fr

To cite this article:

Young, A.S. (2017). "Non, moi je lui dis pas en turc, ou en portugais, ou en, j'sais pas moi en arabe": Exploring teacher ideologies in multilingual/cultural preschool contexts in France. Bellaterra Journal of Teaching \& Learning Language \& Literature, 10(2), 11-24. DOI: http://dx.doi.org/10.5565/rev/jt13.729
\end{abstract}

